\title{
Presettlement phase of Parika scaber (Pisces: Monacanthidae): a temperate reef fish
}

\author{
M. J. Kingsford \& M. J. Milicich* \\ University of Auckland, Department of Zoology, Marine Laboratory, R.D. Leigh, New Zealand
}

\begin{abstract}
Duration of presettlement phase was examined for the temperate reef fish Parika scaber. Information was also collected on seasonality, growth, development, and diet before settlement. Presettlement $P$. scaber associated with drift algae offshore of rocky reefs were of sizes 7 to $35 \mathrm{~mm}$ standard length (SL); highest abundances were found between November and January. Fish just prior to settlement were collected from algae tethered seaward of reefs. Fish associated with drift algae and fish captured around tethered algae had similar size-frequency relationships. Fish that associated with drift and tethered algae and settled on reefs were between 22 and $66 \mathrm{~d}$ old. Despite this wide range of ages and sizes, at any one time a large proportion of $P$. scaber around drift and tethered algae were of a similar size and age. However, among sampling times the mean value for these relations varied. Hence, $P$. scaber have the capacity to settle at a variety of ages and sizes. Presettlement $P$. scaber (described from $3.5 \mathrm{~mm}$ ) have a full adult fin-ray complement and a similar colouration to fish on the reef at 8 to $9 \mathrm{~mm}$ length. Development to the adult form correlated with a change from allometric to isometric growth. Reared and tetracycline-treated fish demonstrated that increments were deposited daily, after hatching, in the sagittal and lapillus otoliths. Assuming that the spacing of increments relates to the growth of fish, a growth curve was determined: After an initial period of slow growth there was a rapid acceleration in growth to $7 \mathrm{~mm}$; growth remained relatively constant in larger fish. The spacing of inciements suggested that development rate varied among samples of fish captured at different times. Growth rates, determined from age-size relations, showed a similar variation. This is discussed in relation to the conditions fish may have experienced in the pelagic enviroment.
\end{abstract}

\section{INTRODUCTION}

In attempting to understand the population dynamics of reef fishes a number of workers have suggested that variation in recruitment is determined by events that occur during presettlement life (Johannes 1978, Doherty 1981, Williams 1983, Jones 1984). Processes likely to influence the survivorship of small fish during this period include: the availability of food, predation, the existence and stability of retention areas, and the condition of spawning fish (Johannes 1978, Mann \& Mills 1979, Lobel \& Robinson 1983, Sissenwine 1984). It is premature, however, to speculate on processes that affect survivorship, as information on the presettlement life of reef fish is very limited (Sale 1980). Although a few studies have described the distribution

\footnotetext{
- Present address: Griffith University, School of Australian Environmental Studies, Nathan, Queensland 4111, Australia

patterns of presettlement reef fish (e. g. Leis \& Miller 1976, Leis \& Goldman 1984, Leis 1986) few data are available on their seasonality, growth, diet, and length of presettlement period; this is especially true for temperate reef fish.

The aims of this study were to obtain information on the seasonal occurrence, duration of the presettlement phase, growth, structural development, and diet of presettlement temperate reef fish Parika scaber (Bloch $\&$ Schneider). With adequate validation, the age and growth history of an individual fish can be obtained from daily increments in the otoliths (for reviews see Campana \& Neilson 1985, Jones 1986). This technique has also been used to estimate the duration of the presettlement phase (Victor 1982, Brothers et al. 1983). The duration of this period may be estimated by aging newly settled fish on the reef. Alternatively, 'settlement marks' in otoliths may allow postsettlement increments to be differentiated from presettlement 
increments (Brothers \& McFarland 1981, Victor 1982, Brothers et al. 1983, Brothers 1984). Results from these 2 approaches suggest that some fish (e. g. Thalassoma bifasciatum; Victor 1982, $1986 \mathrm{a}$, b) settle over a wide range of ages ( 38 to $70 \mathrm{~d}$ ) while others (e. g. Pomacentrus amboinesis; Brothers et al. 1983) show very little variation in age at settlement (19 to $20 \mathrm{~d}$ ). The limited data available suggest that both the mean and range of ages at settlement are species specific for these tropical fishes. No published data are available on the ages of temperate reef fish at settlement.

Information on the growth of small fish can also be obtained from otoliths. It has been demonstrated in some species that there is a good correlation between the width of daily rings and increase in length (Taubert \& Coble 1977) or weight (Wilson \& Larkin 1982). Moreover, ring spacing may change according to the amount of food consumed (Struhsaker \& Uchiyama 1976, Victor 1982, Volk et al. 1984), temperature, and photoperiod (Jones 1986). Assuming that ring spacing is related to growth of small fish during their presettlement life, a history of growth for individual fish can be obtained from the otoliths. Actual growth rates of fish can be estimated from age-size relations. Since food may influence the deposition patterns of otolith increments (Victor 1982, Volk et al. 1984), information on the fish diet would be useful for the interpretation of otolith microstructure. In addition to age and growth, otoliths may provide a chronology of important developmental and behavioural events in the early life history; this may include changes in environmental conditions that the fish experience prior to settlement (Brothers \& McFarland 1981, Campana 1984, Nishimura \& Yamada 1984, Volk et al. 1984).

Leatherjackets Parika scaber are common on rocky reefs around the coast of New Zealand (Russell 1977). With the exception of 2 rare species, $P$. scaber is the only representative of the Monacanthidae around the New Zealand mainland (Ayling \& Cox 1982). Adults feed on encrusting organisms such as sponges and ascidians (Ayling 1981). Although there is little information on other aspects of the life history, large numbers of presettlement $P$. scaber are known to associate with drift algae at inshore and offshore localities in New Zealand (Kingsford \& Choat 1985). The questions we posed were as follows: How do the abundances of presettlement $P$. scaber vary seasonally? Are increments in the otoliths of $P$. scaber deposited daily? At what ages and sizes do $P$. scaber associate with drift algae? At what ages and sizes do $P$. scaber arrive at a reef? What information can be gained on the growth history of presettlement $P$. scaber from otoliths? How does the history of increment deposition compare with changes in the morphology of fish? What are the prey of presettlement $P$. scaber?

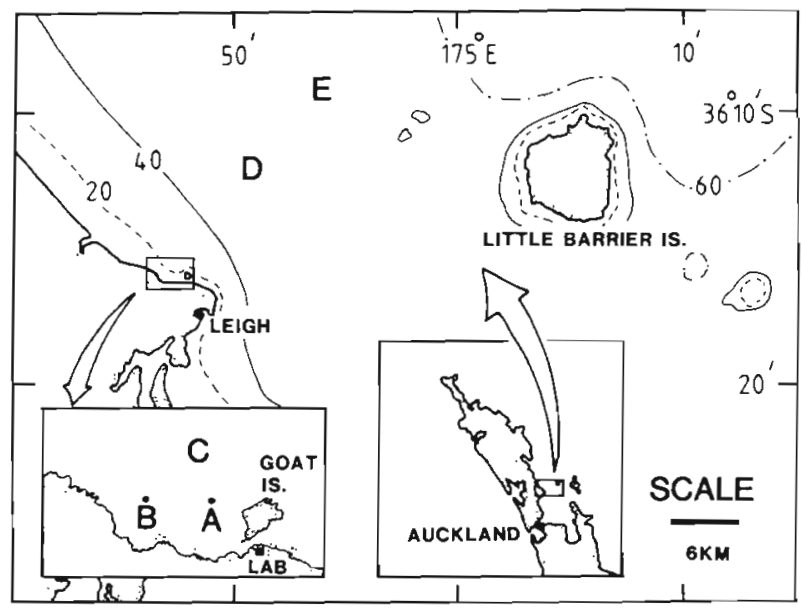

Fig. 1. Map of northeastern New Zealand, showing the stations where drift and tethered algae were sampled; depth contours are given $(\mathrm{m})$. Fish that had settled on the reef were sampled $300 \mathrm{~m}$ to the east of the Laboratory

\section{MATERIALS AND METHODS}

Seasonal patterns. Presettlement Parika scaber were sampled in waters off the northeastern coast of North Island, New Zealand (Fig. 1). Seasonality in the occurrence of presettlement $P$. scaber was investigated by sampling drift algae over an 18 mo period (Dec 1981 to May 1983). Drift algae were sampled using a planktonmesh purse seine net (Kingsford \& Choat 1985) at 2 stations nearshore and 2 offshore; $<100 \mathrm{~m}$ (Stns A \& $\mathrm{B}_{\mathrm{i}}$ Fig. 1), 600 to $800 \mathrm{~m}$ (Stn C), $10 \mathrm{~km}$ (Stn D) and $18 \mathrm{~km}$ (Stn E) from shore. Sampling at each station was carried out within $2 \mathrm{~km}$ zones, parallel to the shore. A minimum of 3 clumps of drift algae were sampled at each station every 2 to 3 mo. Counts were expressed as number per $100 \mathrm{~g}$ of algae. Additional clumps of algae were sampled when presettlement fish were most abundant, in December-January, 1981-1982 ( $\mathrm{n}=22$ clumps) and December-January 1982-1983 ( $\mathrm{n}=23$ clumps). This was to describe the relationship between the weight of an algal clump and the number of fish around it. Furthermore, to test that drift algae could be treated as one group the numbers of $P$. scaber per $100 \mathrm{~g}$ of algae were compared amongst the 4 most abundant species of drift algae in December 1982: Sargassum sinclairii, Carpophyllum maschalocarpum, C. flexuosum, and C. plumosum (Kingsford \& Choat 1985). Five replicate clumps of each species were sampled. Based on seasonal patterns of $P$. scaber, detailed work on presettlement and newly settled $P$. scaber was carried out over the spring-summer periods in the years 1981 to 1985 .

Validation of aging technique. To determine if increments in the otoliths of small Parika scaber were 
deposited daily 2 techniques were used: (1) fish were reared from demersal eggs (Milicich 1986) to an age of $11 \mathrm{~d}$; (2) fish with an adult fin-ray complement were treated with tetralysal. These 2 techniques allowed the deposition of increments to be examined in P. scaber of developmental forms corresponding to the beginning and end of the presettlement phase.

Parika scaber eggs were collected from demersal nests near Goat Island (Fig. 1) and were reared in the laboratory during November 1985. Eggs were incubated in $20 \mathrm{l}$ tanks. The water was aerated and the temperature kept constant by a $40 \mathrm{l}$ water bath. Once fish had hatched, wild plankton captured with a $0.05 \mathrm{~mm}$ mesh net were added to the tank; large zooplankters were removed by grading through $0.11 \mathrm{~mm}$ mesh netting for first feeding fish and $0.28 \mathrm{~mm}$ mesh for older individuals. The tank water temperature was maintained at $15 \pm 1^{\circ} \mathrm{C}$ and 10 to $16 \mathrm{l}$ of water were replaced each day. Following hatching, samples of fish of known ages were preserved in $98 \%$ ethanol. Whenever possible, 2 pairs of otoliths (sagittae and lapilli) were removed and examined from each fish. Accordingly, the pattern of increment deposition could be described and the age at first increment deposition ascertained.

The tetralysal experiment was carried out in November 1984. During treatment with tetralysal the active ingredient (tetracycline) is incorporated into the otolith as it grows. When fish are preserved and the otoliths viewed at a later date, the tetracycline-treated area of the otolith cañ be distinguished as a fluorescent line under ultraviolet light. Tetracycline-based antibiotics have been used to validate the aging technique in other fish (Campana \& Neilson 1982, Ralston \& Miyamoto 1983, Schmitt 1984).

Presettlement Parika scaber were captured around clumps of drift algae at Stn C (Fig. 1). These fish were brought back to the laboratory, then transferred to an 801 tank. Seawater pumped from Goat Island Channel (Fig. 1) was filtered before it entered the tank at 0.8 to $1.21 \mathrm{~min}^{-1}$. Seawater temperature in the tank ranged from 16.0 to $19.0^{\circ} \mathrm{C}$ (mean $=17.8^{\circ} \mathrm{C}$ ), and in Goat Island Channel, 16.8 to $19.0^{\circ} \mathrm{C}$ (mean $=17.5^{\circ} \mathrm{C}$ ). Fish were exposed to a natural light-dark cycle; no artificial light was used. Fish were allowed to acclimatize to tank conditions for $1.5 \mathrm{~d}$ before treatment with tetralysal. They were fed on wild zooplankton and mosquito larvae Opifex fuscus twice a day. Zooplankton were captured in Goat Island Bay with a $0.28 \mathrm{~mm}$ mesh net and mosquito larvae were collected from tide pools.

Sixteen fish (visual estimates: 15 to $24 \mathrm{~mm}$ standard length, SL) were kept in 31 of tetralysal-treated seawater $\left(0.3 \mathrm{~g} \mathrm{l}^{-1}\right)$ for $12 \mathrm{~h}$ overnight (Schmitt 1984). The tetralysal solution was aerated with a bubbler. After treatment the fish were returned to the $80 \mathrm{l}$ tank and fed as previously described for 11 nights and 12 days before they were stored in $98 \%$ ethanol in a cool dark cupboard. At the end of the experiment fish ranged in size from 20.5 to $30.4 \mathrm{~mm}$.

Lapilli and sagittae were dissected out and viewed under fluorescent light and natural light with a Zeiss compound microscope. Under fluorescent light an ocular marker was aligned with the fluorescent band. The preparation was then viewed under natural light and increments counted between the ocular marker and the otolith margin. Increment spacings were measured on both sides of the fluorescent band. This was to check that treatment with tetralysal and conditions in the tank had not affected the deposition of increments. Spacings were measured to the 22 nd increment from the otolith margin in the sagittae of 5 fish, with an ocular micrometer. This corresponded to 11 increments on each side of the fluorescent band. Increment spacings in treated fish caught on 9 November 1984 were compared with a control group of untreated fish $(\mathbf{n}=5)$ captured from Stn D on the same day.

Age-size relations. The age and size ranges of presettlement Parika scaber were described by capturing fish on a number of sampling dates. Presettlement $P$. scaber, associated with drift algae, were captured at Stn D in November $1983(\mathrm{n}=28)$ and $1984(\mathrm{n}=30)$.

As newly settled Parika scaber were secretive and difficult to catch on rocky reefs, tethered algae were used to collect fish just prior to settlement. Clumps of $1 \mathrm{~kg}$ of fucoid algae Carpophylum maschalocarpum were tethered over sediment flats 50 to $100 \mathrm{~m}$ seaward of rocky reefs. The accumulation of incoming fish around algae allowed capture with an opening-closing net $(1.0 \mathrm{~mm}$ mesh, $1.6 \mathrm{~m}$ diameter mouth). Algae were cleared of fish at $48 \mathrm{~h}$ intervals, meaning that fish spent a short time on the collectors prior to capture. Algae were tethered at 1 and $5 \mathrm{~m}$ on ropes at Stns $A$ and $B$ (Fig. 1), where total depth was $20 \mathrm{~m}$. Five ropes were anchored at each station ( $n=5$ clumps of algae at each depth). Fish were collected from algae in January 1985 $(\mathrm{n}=54)$, February $1985(\mathrm{n}=11)$, November 1985 ( $\mathrm{n}=$ $60)$, December $1985(\mathrm{n}=60$ ) and January 1986 ( $\mathrm{n}=$ 63 ) for the examination of otoliths. Following capture fish were fixed in $98 \%$ ethanol. Newly settled $P$. scaber were speared in February 1985 ( $n=10$ ) and December 1985 ( $n=12$ ) from forests of laminarian algae Ecklonia radiata where settlement was highest (Milicich 1986). Furthermore, visual estimates of the sizes of fish over laminarian forest were made in six $25 \times 10 \mathrm{~m}$ transects at each of 3 localities around Goat Island in December 1984. Additional fish were captured around drift (1982 to $1985 ; \mathrm{n}=371$ ) and tethered algae (1984 to $1986 ; n=200$ ) to measure their size frequencies. These fish were fixed in $2 \%$ formalin and freshwater, a combination which caused very little 
change to live length (Tucker \& Chester 1984). Length comparisons among fish fixed in ethanol or formalin were considered valid. This was because tests done on $P$. scaber, and other small fish, showed that changes in length due to the different fixatives were difficult to differentiate from measurement error. Where $P$. scaber over a size of $10 \mathrm{~mm}$ were measured with calipers, remeasured fish showed an error of up to $1 \mathrm{~mm}$.

Spacing of otolith increments. The spacing of increments was measured in presettlement fish and in Parika scaber just prior to settlement to determine how the increment pattern changed with distance from the otolith primordium and, how this relation compared among groups of fish. Measurements were made with an ocular micrometer along a radius from the primordia (sensu Brothers \& McFarland 1981) of sagittae, in an area where the radius was greatest. Only sagittae with a clear view of increments along this radius were used. The spacing of increments were examined in 6 groups of fish ( $\mathrm{n}=5 \mathrm{fish}$ ) associated with: drift algae, November 1983, 1984; tethered algae, November 1985, December 1985, January 1985, 1986.

Morphometric changes and terminology. The morphometric characteristics and pigmentation patterns of Parika scaber were described, to determine the sizes at which fish obtain adult fin-ray counts and the morphology and colour of fish on rocky reefs. A series of $P$. scaber was obtained from ichthyoplankton hauls, and purse seines around drift algae, within $30 \mathrm{~km}$ of the Marine Laboratory (1984 to 1985). These 40 fish ranged in size from 3.5 to $27 \mathrm{~mm}$. The lengths of fish refer to standard length, or in the case of very small fish, notochord length. Our description of morphological characters follows the general terminology of Leis \& Rennis (1983). The presettlement phase refers to the period from egg hatching to settlement (sensu Williams 1983) on a reef. It was inappropriate to call this phase the larval stage (e.g. Victor 1986a) as small $P$. scaber may spend a considerable period in the pelagic environment as juveniles.

Diet of presettlement Parika scaber. Fish were captured around drift algae at Stns D and E during the summer of 1981-1982, to examine their gut contents. The number and proportional representation were recorded for each food type in each fish. Proportional representation was measured using the intersection method detailed by Jones (1968).

Laboratory procedure. For the examination of otoliths, the sagittae and lapilli were dissected out of each fish if possible. Otoliths were mounted on a slide in immersion oil. Although rings were observed in sagittae and lapilli, they were more easily seen in the sagittae. All counts were made at magnifications of 400 to $1000 \times$ with a Nikon compound microscope. Contrast was enhanced with a neutral density filter. Con- centric dark rings on an otolith were each counted as individual increments. The major source of error in reading otoliths was counting rings near to the primordium. Close to the primordium, increments were separated by less than $1 \mu \mathrm{m}$ and were the hardest to observe; even at $1000 \times$. Hence, some variability in the precision of counts could be expected in this area. Three readings were made from each sagitta and the mean value was used if the 6 individual counts varied by less than 2 about the mean; fish were rejected from analyses if they did not comply with this condition. In cases where one sagitta was difficult to read it was rejected and only counts from the other sagitta were used. Bias on the part of the reader was also examined, as it was possible that the first replicate reading would influence subsequent counts. Following the initial counts the coded slide was examined at a later date by the same author and by the other author. This procedure of triple readings was carried out for 5 pairs of otoliths from presettlement fish and fish just prior to settlement $(\mathrm{n}=10 \mathrm{fish})$. Age estimates indicated that the greatest difference in our estimates was $4 \mathrm{~d}$. The values were [maximum difference in days (frequency)]: 1 (3), 2 (2), 3 (3), 4 (2).

\section{RESULTS}

\section{Seasonal patterns of Parika scaber associated with drift algae}

Although Parika scaber were sometimes captured around drift algae in autumn and winter, their seasonal peak in abundance commenced in October-November, peaked in November to January and dropped off in February (Fig. 2). Fish were caught in highest abundances at stations offshore. When presettlement fish were abundant around algae, at offshore stations there was a positive correlation between the size of algal clumps and the number of fish associated with them. This was found in December-January 1981-1982 where individual $P$. scaber were found around 4 to $5 \mathrm{~g}$ clumps of algae and 112 fish were associated with a $1450 \mathrm{~g}$ clump $(\mathrm{r}=0.96, \mathrm{n}=22$ clumps $)$. A similar, although more variable correlation was found in December-January 1982-1983 ( $\mathrm{r}=0.77, \mathrm{n}=23$ clumps). Individual fish were found around $40 \mathrm{~g}$ clumps of algae, while at the other end of the scale 80 $P$. scaber were associated with a $600 \mathrm{~g}$ clump. All types of algae were lumped for these analyses as the densities of $P$. scaber per $100 \mathrm{~g}$ of algae did not vary significantly among algae of different species (mean \pm $\mathrm{SE})$ : Sargassum sinclairii $(5.7 \pm 1.3)$, Carpophyllum maschalocarpum $(5.4 \pm 2.8)$, C. flexuosum $(11 \pm 6.1)$, C. plumosum (4.4 \pm 1.9$)$; $\mathrm{df}=3,16, \mathrm{~F}=0.58$. 


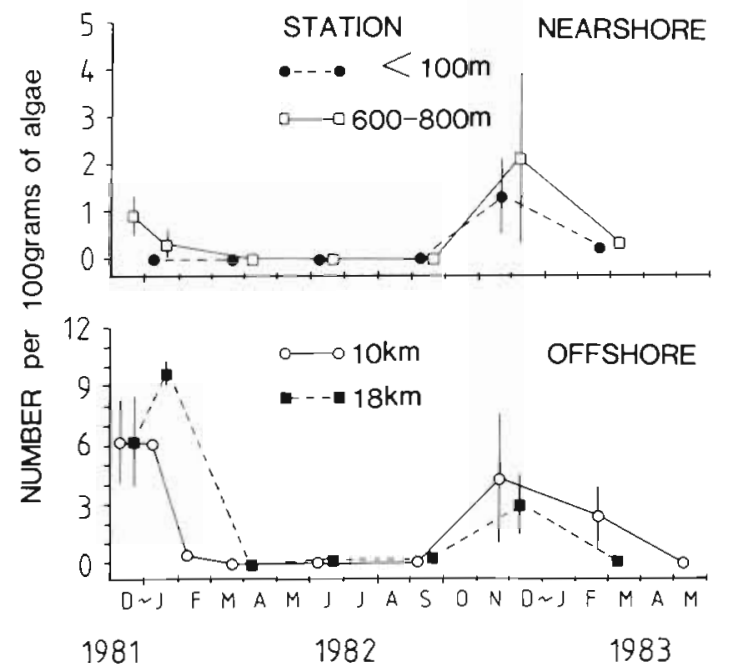

Fig. 2. Parika scaber. Number of fish associated with drift algae at nearshore and offshore stations over a period of 18 mo. Collections are expressed as mean $\pm \mathrm{SE}, \mathrm{n}=3$ clumps of algae

\section{Rearing and tetralysal experiments}

From egg hatching to $8 \mathrm{~d}$ old there was a one-to-one relation between the age of fish in days and number of sagittal and, where inspected, number of increments in lapilli (Table 1A). The first increment was formed at the end of the first day after hatching. For the first few days of the presettlement phase, therefore, otolith incremont deposition is a daily event.

Increments were deposited daily in the sagittae and lapilli of Parika scaber with adult fin-ray counts (Table

Table 1. Parika scaber. Validation of aging. (A) Results of rearing experiment. Chronological age (days from hatching) and numbers of growth increments in otoliths; $\mathrm{n}=5$ fish. (B) Results of tetralysal experiment. Fish were preserved $12 \mathrm{~d}$ after treatment with tetralysal. The table shows the number of increments observed between the fluorescent band and the margin of the otolith

\begin{tabular}{|c|c|c|c|}
\hline \multicolumn{4}{|c|}{ A. Rearing experiment } \\
\hline Age (d) & Sagittae & Lapilli & Range \\
\hline 1 & 1 & - & 0 \\
\hline 4 & 4 & 4 & 0 \\
\hline 6 & 6 & 6 & 0 \\
\hline 8 & 7.5 & - & $7-9$ \\
\hline \multicolumn{4}{|c|}{ B. Tetralysal experiment } \\
\hline Otolith & \multicolumn{2}{|c|}{ Sagittae } & Lapilli \\
\hline Mean $\pm \mathrm{SE}$ & \multicolumn{2}{|c|}{$11.2 \pm 0.1$} & $11.1 \pm 0.2$ \\
\hline Range & \multicolumn{2}{|c|}{$10-12$} & $10-12$ \\
\hline No, of fish & \multicolumn{2}{|c|}{16} & 11 \\
\hline
\end{tabular}

1B). When viewed under natural light a mean of 11 increments was counted from the fluorescent band to the margin of sagittae and lapilli. Fig. 3 shows the fluorescent band in a sagitta. Dark increments may be laid down at night, as the mean count of 11 corresponded to the number of nights fish were alive following the treatment.

Increment spacing was similar in Parika scaber before they were captured and treated with tetralysal, and for the $12 \mathrm{~d}$ following treatment (Fig. 4). Assuming that increment spacing related to the growth of fish, it suggested that fish were not deleteriously affected in tank conditions. In addition, increment spacings were almost identical to those in the otoliths of untreated fish captured at Stn D (Fig. 4).

\section{Sizes of presettlement and settled Parika scaber}

Presettlement Parika scaber captured around drift algae ranged in size from 6.8 to $34.6 \mathrm{~mm}$ (Fig. 5). Fish captured around tethered algae ranged in size from 8 to $24 \mathrm{~mm}$. In general, however, the smallest fish associated with drift and tethered algae were 11 to $12 \mathrm{~mm}$ and mean values varied between times. All fish were well pigmented and had a full adult fin-ray count.

In November 1984, fish collected around drift and tethered algae in the same week had very similar size distributions (Fig. 5). The mean size of fish around drift algae was slightly lower than on tethered algae. This relation suggested that all presettlement fish associated with drift algae were capable of settling on the reef. Further evidence comes from visual estimates of fish sizes over areas of reef in December 1984. The smallest fish seen were 10 to $12 \mathrm{~mm}$, and of the fish observed in counts, $71 \%$ were 10 to $20 \mathrm{~mm}, 17 \%$ were 20 to $30 \mathrm{~mm}$, and $12 \%$ were 30 to $40 \mathrm{~mm}$ ( $\mathrm{n}=147$ ). In addition, Jones \& Poynter (unpubl. data) speared $P$. scaber over reefs in November 1978 which were 15 to $42 \mathrm{~mm}(\mathrm{n}=42)$. The data indicate, therefore, that $P$. scaber are capable of settling from $9 \mathrm{~mm}$, but presettlement fish may be captured in offshore waters up to a size of $34.6 \mathrm{~mm}$.

The size frequency of Parika scaber around drift and tethered algae varied among the times it was measured (Fig. 5). For example, a much greater range of fish sizes were captured around drift algae in November 1983 than in 1984. Similarly, with tethered algae, the range and mean size of fish were higher in November 1984 than in January 1985. This suggested that at different times fish may spend varying periods in the pelagic environment, and/or have varying growth rates before settling. Although a broad size range of fish were captured around drift and tethered algae at any one time, many fish were of a similar size. 

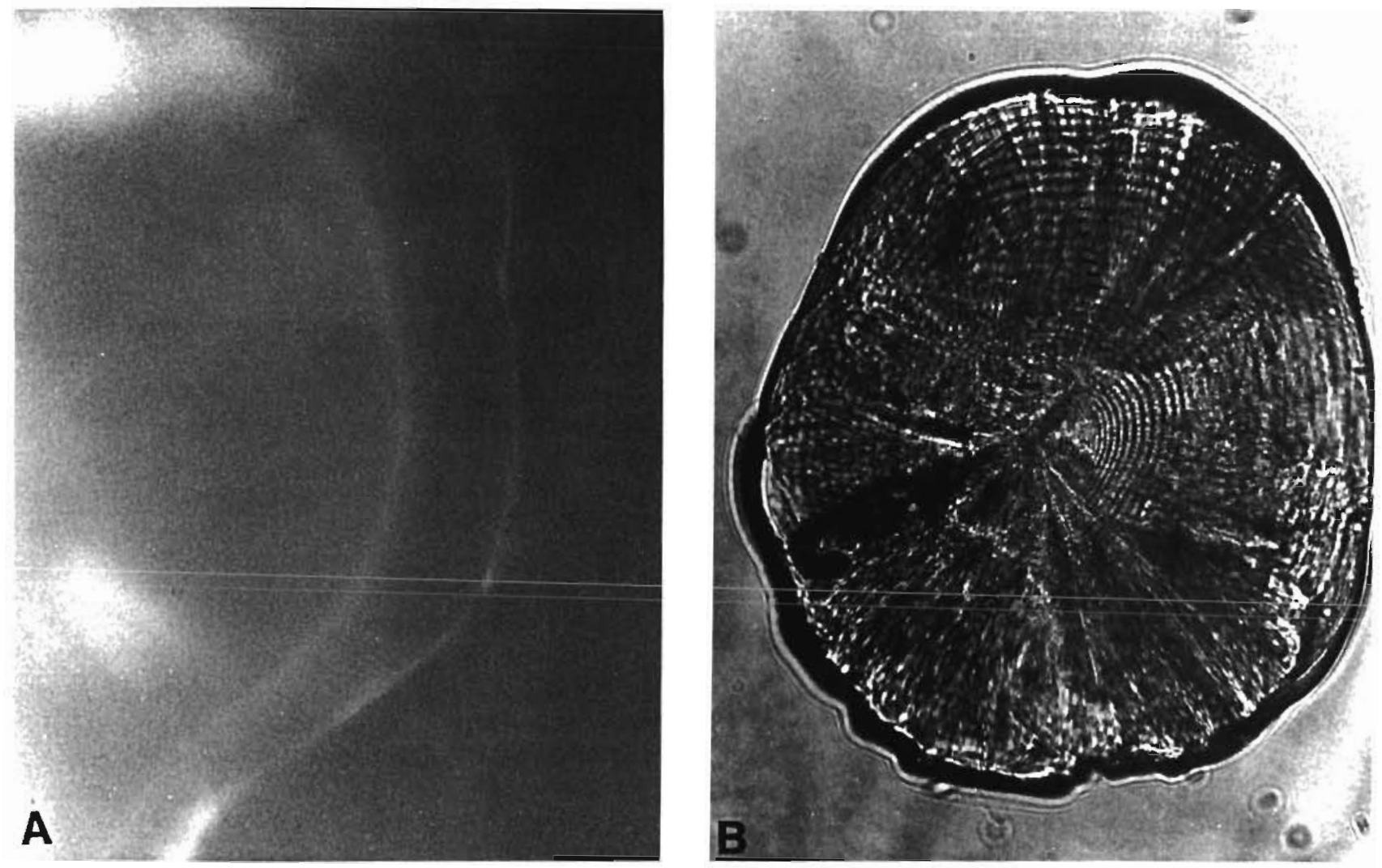

Fig. 3. Parika scaber. (A) Sagitta viewed under ultra-violet light. A tetralysal marker can be seen as a fluorescent line. (B) Sagitta of a $36 \mathrm{~d}$ old fish viewed under natural light

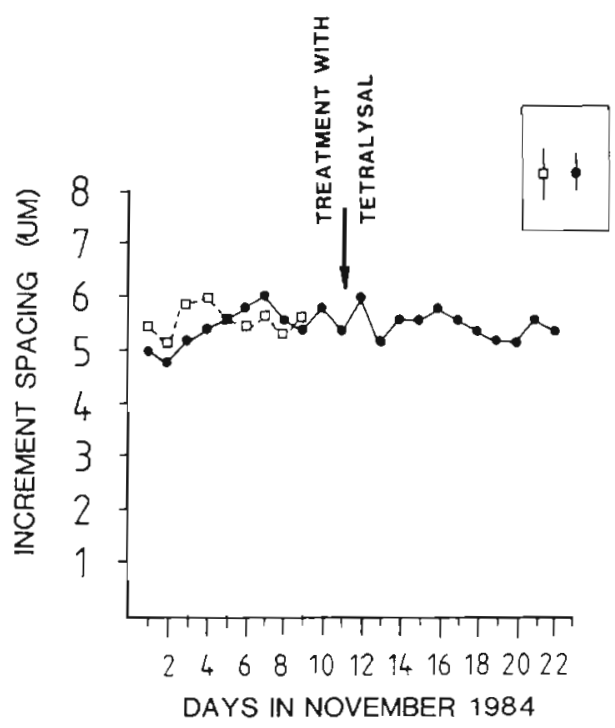

Fig. 4. Parika scaber. Spacings of otolith increments which represent the growth of fish before and after treatment with tetralysal. (-) treated fish; ( $\square$ ) fish captured and preserved at Stn D on 9 Nov 1984. The first 9 points represent the spacings of increments deposited while the fish were still in the field, prior to capture. Increments after the tetralysal marker were deposited while fish were held in the tank. Average standard errors are given for both groups of fish in the box
For example, in January 1985 fish around tethered algae (i.e. potential settlers) ranged in size from 9 to $17 \mathrm{~mm}$, and of these $77 \%$ were 14 to $17 \mathrm{~mm}$. This indicated that, at this time, most fish settled at a size close to the minimum size $P$. scaber are likely to associate with algae. Unlike size frequency relations of fish around drift or tethered algae at other times, in November 1983 there was no obvious peak size class over a wide range (Fig. 5).

\section{Ages of presettlement and settled Parika scaber}

Daily increments in the sagitta of a presettlement Parika scaber are shown in Fig. 3B. The youngest fish found around algae, whether drift or tethered, was $22 \mathrm{~d}$ and the oldest, $66 \mathrm{~d}$ old (Fig. 6). Hence, fish from a wide range of ages were sampled.

Presettlement fish (13 to $28.5 \mathrm{~mm}$ ) captured around drift algae in November 1983 (Fig. 6A) were between 37 and $66 \mathrm{~d}$ old. Average sized fish $(19.3 \mathrm{~mm})$ that associated with drift algae at this time were approximately $49 \mathrm{~d}$ old. In November 1984 the fish captured were on average smaller (mean $15.6 \mathrm{~mm}$, range 10 to $22 \mathrm{~mm}$ ) with an approximate age of $40 \mathrm{~d}$ (Fig. 6B). 
Fig. 5. Parika scaber. Size frequency distributions of fish captured around drift and tethered algae 1982 to 1986 . Standard lengths were compared with notochord lengths in small fish
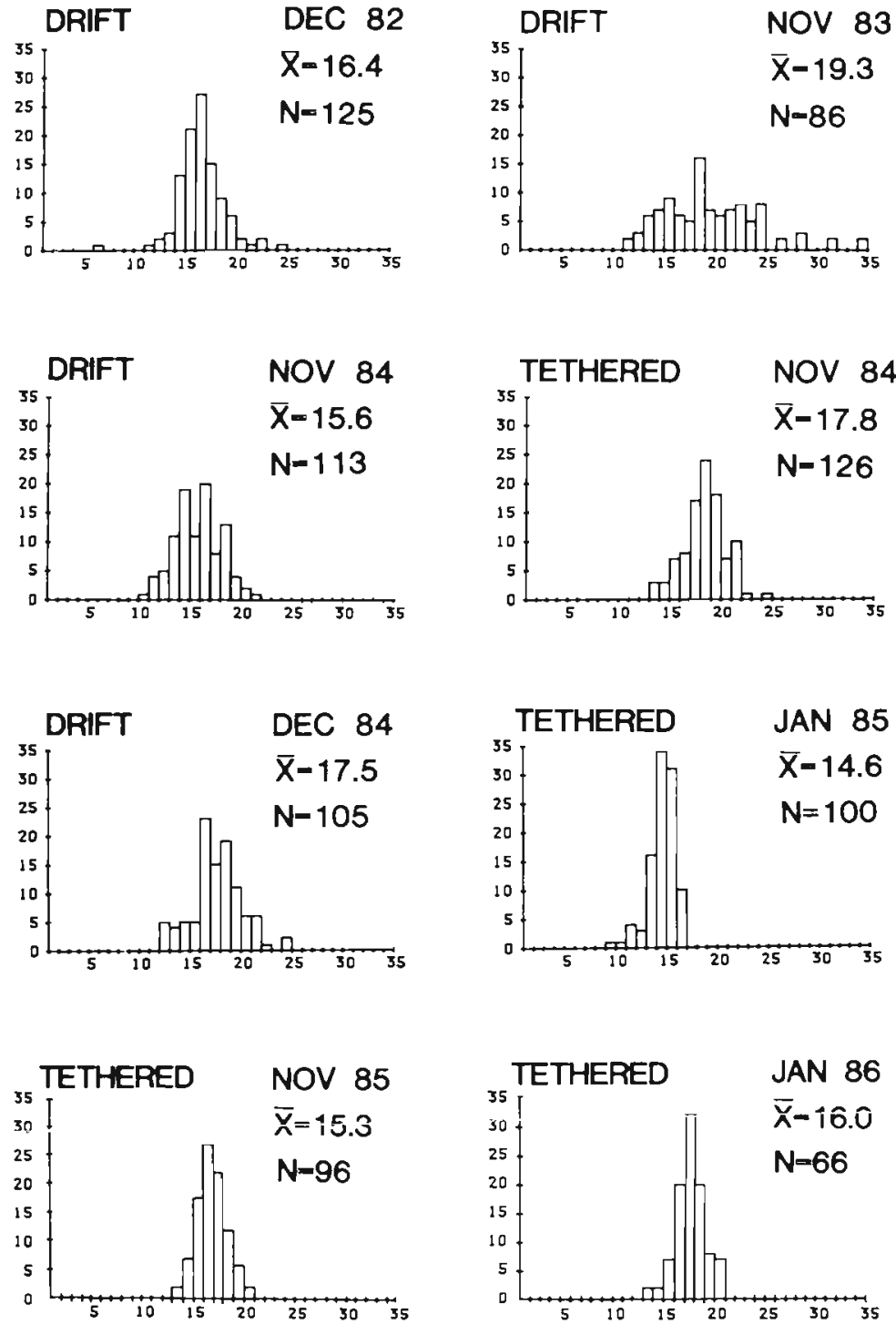

\section{MM SIZE CLASSES}

These fish ranged in age from 30 to $52 \mathrm{~d}$. Thus the mean age and range varied among times. Note that the above were the age distributions present, not the ages at which fish became associated with drift algae.

On tethered algae fish as young as $22 \mathrm{~d}$ (at $8 \mathrm{~mm}$ ) were captured in January 1985. Fish ranged in age from 22 to $44 \mathrm{~d}$. The approximate age of an average sized fish $(14.4 \mathrm{~mm})$ was $31 \mathrm{~d}$. An additional 11 fish were captured around tethered algae in February 1985. The ages of these fish varied from 30 to $58 \mathrm{~d}$ and they had a similar age-size relation to January fish (Fig. 6C). In November 1985 fish ranged in age from 30 to $50 \mathrm{~d}$ and the age of an average sized fish $(15.3 \mathrm{~mm})$ was $40 \mathrm{~d}$. A similar range of ages was found in December
1985. However in January 1986, Parika scaber ranged in age from 29 to $37 \mathrm{~d}$ with a mean age of $31 \mathrm{~d}$. Although there was a wide range of ages many potential settlers were of a similar age. For example, in January 1985 fish ranged in ages from 22 to $44 \mathrm{~d}$. But, $77 \%$ of these fish were 31 to $36 \mathrm{~d}$ old. Thus, the mean age and range varied among times, as for fish associated with drift algae.

No settlement marks were found in the otoliths of postsettlement fish captured during February and December 1985 in laminarian forests on the reef (16 to $76 \mathrm{~mm}, \mathrm{n}=22$ ). Hence, there was no way of distinguishing presettlement from postsettlement increments. This indicated that the only way of describing age-size 

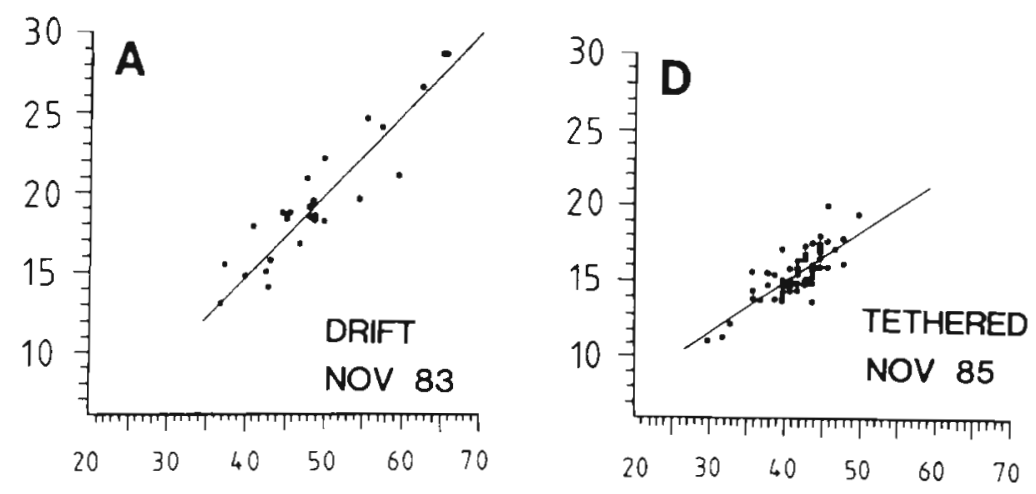

NO. OF DAILY INCREMENTS
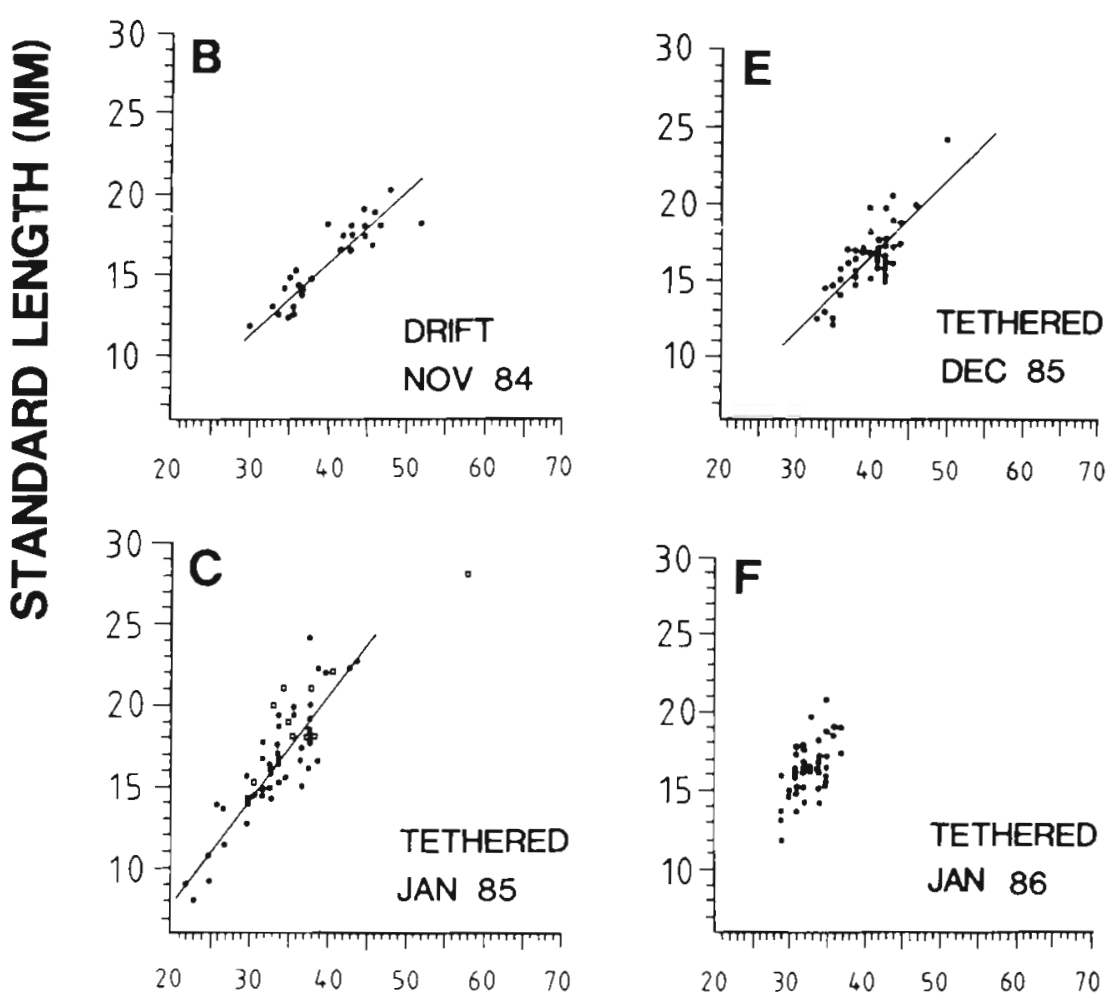

Fig. 6. Parika scaber. Relations between the age of fish and standard length. (A) Drift algae, Nov 1983; $y=$ $0.47 \mathrm{x}-4.59, \mathrm{R}^{2}=0.86$ (B) Drift algae, Nov 1984; $y=0.41 \mathrm{x}-0.67, \mathrm{R}^{2}=0.82$ (C) Tethered algae, ( Jan 1985; $y=$ 0.64x-5.18, $R^{2}=0.76$. ( $\square$ ) Feb 1985; not included in calculation of the regression line. (D) Tethered algae, Nov 1985; $y=0.34 \mathrm{x}+1.36, \mathrm{R}^{2}=0.50 .(\mathrm{E})$ Tethered algae; $\mathrm{y}=0.50 \mathrm{x}-3.38, \mathrm{R}^{2}=$ 0.62. (F) Tethered algae, Jan 1986; no regression (see text) relations at settlement was from the regular clearing of fish just prior to settlement from tethered algae. Small fish captured on the reef ranged in ages from 32 to $73 \mathrm{~d}$.

The growth rates of all groups of fish were linear, however the slopes varied among times (Fig. 6). Slopes of 5 of the relations between age and length ( $A$ to $E$ ) were compared using an analysis of covariance; this indicated there were significant differences ( $\mathrm{df}=$ 4,$223 ; \mathrm{F}=7.1, \mathrm{p}<0.001$ ). Lowest growth rates were measured in November and highest in January. It was considered inappropriate to include January 1986 data in the analysis as a relatively low size range of fish were captured, with many of these being of a similar age and size; this would have weighted any calculation of the relation. The differences in growth rates among times were clearly seen by comparing the ages of fish at $12 \mathrm{~mm}$ for the 6 groups in Fig. 6. In November 1983 these fish were approximately $37 \mathrm{~d}$ old, in November $1984,30 \mathrm{~d}$, in January 1985, $28 \mathrm{~d}$, in November 1985, 32 d, in December 1985, 30 d, in January $1986,27 \mathrm{~d}$.

\section{Spacing of otolith increments}

The spacing of otolith increments changed with distance from the primordium (Fig. 3B \& 7). In all groups examined there was a similar trend. For the first 5 to $12 \mathrm{~d}$ increments were close together followed by a rapid increase in increment spacing. At 22 to $33 \mathrm{~d}$ 
Fig. 7. Parika scaber. Relations between the number of daily increments and spacing of increments. (A) Drift algae, Nov 1983. (B) Drift algae, Nov 1984. (C) Tethered algae, Jan 1985. (D) Tethered algae, Nov 1985. (E) Tethered algac, Dec 1985. (F) Tethered aigae, Jan 1986. Mean \pm range, $n=5$ fish; the range was more conservative than $95 \%$ CL. Numerals above (B) and (C) indicate decreasing replication from 5 fish

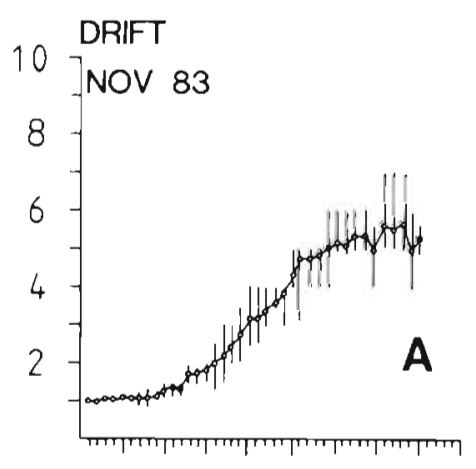

$5 \quad 101520 \quad 2530 \quad 3540 \quad 45$

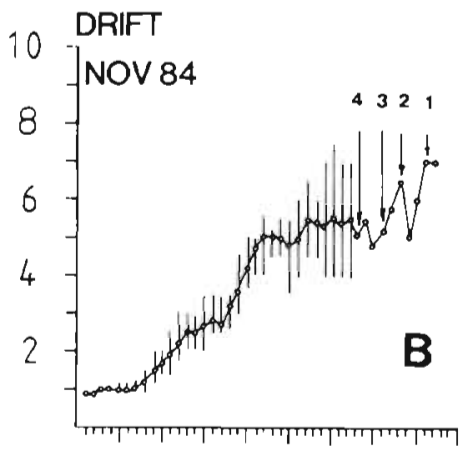

$5 \quad 10 \quad 152025 \quad 3035 \quad 40 \quad 45$

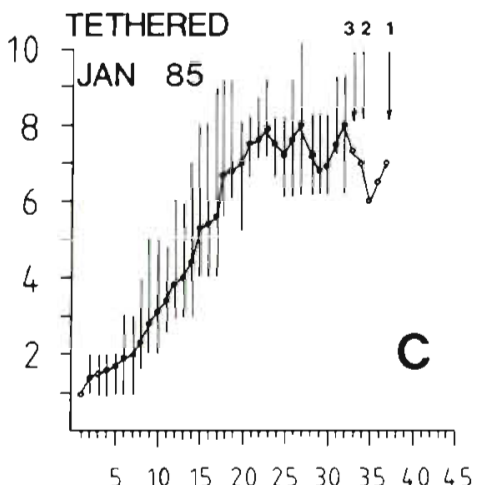

$\begin{array}{lllllllll}5 & 10 & 15 & 20 & 25 & 30 & 35 & 40 & 45\end{array}$

NO. OF DAILY INCREMENTS
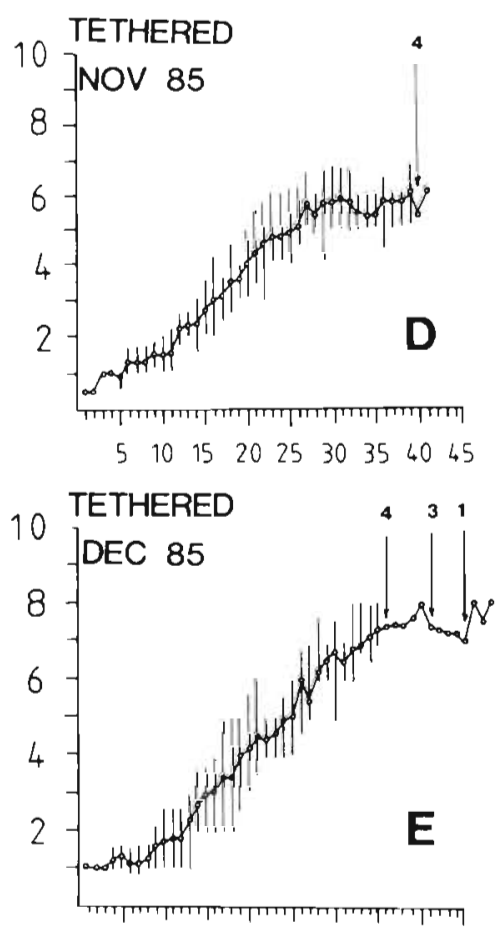

$5 \quad 10 \quad 1520 \quad 2530 \quad 35 \quad 40 \quad 45$

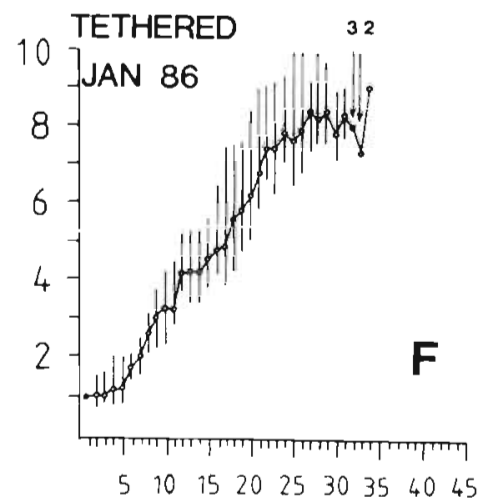

average spacings reached a plateau. The spacing of increments in all individuals oscillated by up to $3 \mu \mathrm{m}$ between days at this stage. This plateau corresponds with the linear (isometric) growth of fish shown in the age-size relations (Fig. 6).

The relation between the number of daily increments and the spacing of increments varied among groups of fish (Fig. 7). Assuming the spacing of increments reflected the growth history of individual Parika scaber during their presettlement phase, the fish caught in 1983 (Fig. 7A) grew slower than the other groups. These fish grew little for the first $12 \mathrm{~d}$ and the plateau was not reached for $33 \mathrm{~d}$. Fish caught at other times grew more quickly and the plateau was reached earlier (Fig. 7B to F). P. scaber captured in January
1985 and 1986 grew quickly and the plateau was reached at a higher mean increment spacing than for the other groups of fish. These data suggest that the development rate of $P$. scaber may vary.

\section{Morphometric changes in presettlement Parika scaber}

A description of the development of fin-rays and other morphological features is given in Fig. 8. The smallest Parika scaber captured in ichthyoplankton nets was $3.5 \mathrm{~mm}$. This fish only had a dorsal spine bud, a finfold, and a straight notochord. At approximately 


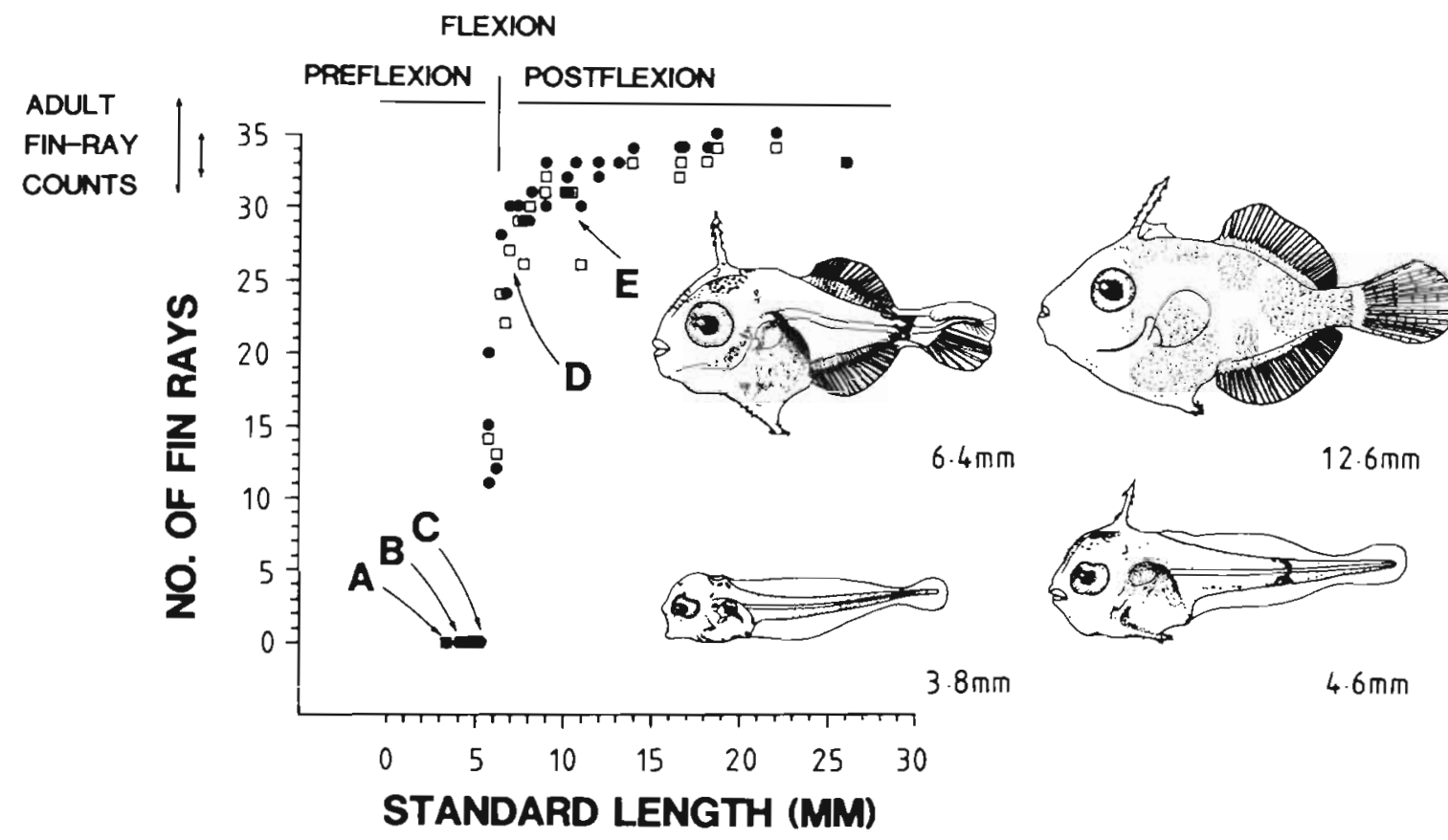

Fig. 8. Parika scaber. Morphometric changes ( $\mathrm{n}=40 \mathrm{fish}$ ). Relation between standard length (notochord length in very small fish) and number of fin rays. The size where flexion of the notochord occurs is indicated. Development: (A) dorsal spine bud; (B) dorsal spine formed, spinules on the head; (C) dorsal and anal rays appear from anlagen, body deepens; (D) flexion of the notochord, caudal rays develop; (E) well pigmented, same appearance as settled fish on reefs. (๑) Dorsal fin-rays; ( $\square$ ) anal fin-rays

$4.0 \mathrm{~mm}$ the dorsal spine has developed and small spinules (precursor of the specialized adult scales; Aboussouan \& Leis 1984) are visible in front of the eyes. In fish over $5 \mathrm{~mm}$ long the dorsal and anal fin anlagen are visible. By the time fish are $5.7 \mathrm{~mm}$ long, fin-rays are visible, protruding from the ray base. Flexion of the notochord takes place at approximately $6.5 \mathrm{~mm}$ and the caudal rays (12 in aلl) develop. The finray counts are less than those of adult $P$. scaber at this size. Only the head and the caudal peduncle are well pigmented, as they are in $4.6 \mathrm{~mm}$ fish (Fig. 8).

At 8 to $9 \mathrm{~mm}$ Parika scaber have a full fin-ray count and have a similar pigmentation to fish on the reef. This was true for presettlement fish caught in ichthyoplankton tows and around drift algae. Fish from 7 to $9 \mathrm{~mm}$ have been captured in association with drift and tethered algae. $P$. scaber captured at between 8 and $9 \mathrm{~mm}$ in January 1985 were 22 to $23 \mathrm{~d}$ old (Fig. 6C). This age ties in well with the beginning of the plateau in increment spacing shown in Fig. $7 \mathrm{C}$. These data suggest that the rapid increase in growth from 8 to $20 \mathrm{~d}$ (Fig. 7C) coincides with the early development of $P$. scaber from a simple preflexion fish to a welldeveloped fish with structures similar to the adult. Furthermore, although presettlement fish were captured at sizes up to $34 \mathrm{~mm}$, they had completed their development to an adult form at 7 to $9 \mathrm{~mm}$.

\section{Diet of presettlement Parika scaber}

The composition of prey in the guts of presettlement Parika scaber varied among the times it was examined (Table 2). In December and February 33 to $66 \%$ of prey volume was crab megalopa. Crab megalopa are abundant epiphytal invertebrates on drift algae (Kingsford $\&$ Choat 1985). The remainder of the prey were zooplankters e.g. polychaete larvae, calanoid copepods, and fish eggs. In January very few megalopa were found in the guts of fish. On this occasion euphausids were abundant in the guts, along with other zooplankters. Although crab megalopa were on the algae (190 \pm 57 per $100 \mathrm{~g}$ of algae, $\mathrm{n}=3$ clumps of algae), euphausiids were consumed. These data suggested that $P$. scaber may eat epiphytal invertebrates from the algae and zooplankters from the surrounding waters. However, when zooplankton is very abundant fish may eat only zooplankton.

Some variance in the \% occurrence of megalopa in fish could be attributed to size-related differences in diet. Parika scaber (Dec and Feb samples) from 7 to $15 \mathrm{~mm}$ (mean $=12.5 \mathrm{~mm}, \mathrm{n}=9$ ) had no megalopa in their guts, while fish from 17 to $28 \mathrm{~mm}$ (mean $22.2 \mathrm{~mm}$, $n=9)$ had $62.4 \pm 11 \%$ volume of megalopa in their guts. It seems that presettlement fish $<15$ to $16 \mathrm{~mm}$ feed mainly on zooplankton, while larger fish also feed 
Table 2. Parika scaber. Diet of fish captured around drift algae 10 to $18 \mathrm{~km}$ offshore of Goat Island. Mean \pm SE values are given for proportional representation (\% rep) and number (No.) of prey items in the guts. Percentage occurrence of prey items is also given ( $\%$ occ.)

\begin{tabular}{|c|c|c|c|c|c|c|c|c|c|}
\hline \multirow[t]{2}{*}{ Prey type } & \multicolumn{3}{|c|}{ Dec 1981} & \multicolumn{3}{|c|}{ Jan 1982} & \multicolumn{3}{|c|}{ Feb 1982} \\
\hline & $\%$ rep. & No. & $\%$ occ. & \% гер. & No. & $\%$ occ. & $\%$ rep. & No. & $\%$ occ \\
\hline \multicolumn{10}{|c|}{ MACRO-CRUSTACEA } \\
\hline Crab megalopa & $67 \pm 16.4$ & $2.1 \pm 0.7$ & 67 & $3.5 \pm 2.6$ & $0.2 \pm 0.3$ & 17 & $33.6 \pm 6$ & $2.5 \pm 0.5$ & 64 \\
\hline Crab zoea & 0 & 0 & 0 & 0 & 0 & 0 & $0.4 \pm 0.4$ & $0.03 \pm 0.03$ & 3 \\
\hline Shrimp larvae & 0 & 0 & 0 & 0 & 0 & 0 & $0.5 \pm 0.5$ & $0.09 \pm 0.07$ & 6 \\
\hline Euphausids & 0 & 0 & 0 & $54.6 \pm 11.3$ & $3.9 \pm 1$ & 75 & 0 & 0 & 0 \\
\hline \multicolumn{10}{|l|}{ COPEPODS } \\
\hline Termora & 0 & 0 & 0 & $12.3 \pm 7.5$ & $6.3 \pm 5.5$ & 42 & $1.1 \pm 1.0$ & $0.4 \pm 0.1$ & 24 \\
\hline Paracalanus & 0 & $0.1 \pm 0.1$ & 11 & $2.3 \pm 2.1$ & $0.4 \pm 0.3$ & 25 & $0.5 \pm 0.5$ & $0.1 \pm 0.05$ & 9 \\
\hline Coryceus & 0 & 0 & 0 & 0 & $0.08 \pm 0.08$ & 8 & $0.5 \pm 0.5$ & $0.2 \pm 0.1$ & 12 \\
\hline \multicolumn{10}{|l|}{ OTHERS } \\
\hline Polychaete larvae & 0 & 0 & 0 & 0 & 0 & 0 & $55.5 \pm 9.7$ & $34 \pm 5.3$ & 100 \\
\hline Fish eggs & $19 \pm 6.1$ & $2.6 \pm 1.2$ & 55 & $26.2 \pm 7.5$ & $3.6 \pm 0.9$ & 83 & $4.6 \pm 2.0$ & $0.8 \pm 0.3$ & 36 \\
\hline Miscellaneous & $9 \pm 6.1$ & $1.1 \pm 0.6$ & 44 & 0 & $0.2 \pm 0.2$ & 17 & $0.8 \pm 0.5$ & $1.6 \pm 0.6$ & 36 \\
\hline No. of fish & & 9 & & & 12 & & & 33 & \\
\hline Size range (mm) & & $14.7-28.1$ & & & $12.9-30$ & & & $10-28$ & \\
\hline
\end{tabular}

on epiphytic invertebrates. Casual observations on $P$. scaber held in tanks showed that fish fed voraciously on any salps and ctenophores that were given to them. Hence, gelatinous zooplankton may also form part of the diet when they are an abundant component of the plankton. These would be particularly difficult to identify in stomach contents.

\section{DISCUSSION}

\section{Validation of aging}

It was demonstrated that increments were deposited daily in the otoliths of Parika scaber during the early presettlement phase to an age of $8 \mathrm{~d}$. First increments in the otoliths of fish may be deposited prior to egg hatching, hatching, just after hatching or first feeding (Brothers et al. 1976, Radtke \& Waiwood 1980, Tsuji \& Aoyama 1982, Wilson \& Larkin 1980). In the case of $P$. scaber, the first increment was formed at the end of the first day after hatching.

Tetracyline gave unequivocal fluorescent markers on the otoliths of fish with adult fin-ray counts. This confirmed that increments in the otoliths were also deposited daily in Parika scaber toward the end of the presettlement phase. From these data it was concluded that presettlement $P$. scaber could be accurately aged using daily increments.

A review by Jones (1986) drew attention to the possibility that rearing conditions may alter the deposition rates of increments in otoliths. Temperatures in our tetralysal and rearing experiments were the same as those in the sea and the light-dark cycle was natural (see 'Materials and Methods'). Furthermore, in the tetralysal experiment, growth (inferred from increment spacings) was similar in the field, before fish were captured, and during the experiment. In treated fish increments spacings were also similar to untreated fish. This indicated that conditions in the tank probably equated with those in the field.

\section{Age and size at settlement}

There were no settlement marks in the otoliths of Parika scaber on rocky reefs. Because there was no way of distinguishing presettlement from postsettlement increments, ages and sizes near the time of settlement could only be estimated by regularly collecting potential settlers from tethered algae. Settlement marks have been found in the otoliths of many tropical and subtropical fishes (e.g. Brothers et al. 1983, Victor 1983), but there are no comparable publications on temperate reef fish. Settlement marks have been found in the otoliths of the temperate pomacentrid Chromis dispilus (Kingsford unpubl. data), so the absence of marks in the otoliths of $P$. scaber is unlikely to be a general trend for temperate reef fish. Checks in otoliths are thought to be a function of physiological stress experienced during a transition: ecological, behavioural, and/or morphological (Nishimura \& Yamada 1984, Campana \& Neilson 1985, Victor 
1986b). When $P$. scaber settle on rocky reefs they associate with forests of laminarian algae Ecklonia radiata and feed upon epiphytic invertebrates (Poynter unpubl. data). Many $P$. scaber already feed on epiphytic invertebrates from drift algae before they settle on the reef. As settlement marks are associated with 'ecobehavioural' changes in the fish (Brothers \& McFarland 1981), this may explain why no settlement marks were found in $P$. scaber. Presettlement fish effectively adopt the feeding behaviour of fish on the reef before they have settled.

Comparisons among Parika scaber around drift algae, tethered algae, and on rocky reefs, indicated that any presettlement fish associated with drift and tethered algae were capable of settling. Our data indicated that $P$. scaber can settle on rocky reefs at very small sizes, between 8 and $12 \mathrm{~mm}$. The youngest fish that we sampled around iethered aigae was aged $22 \mathrm{~d}$ $(8 \mathrm{~mm})$. At times, however, presettlement fish were found on drift algae offshore at sizes of up to $34.6 \mathrm{~mm}$. A total size range of 8 to $34.6 \mathrm{~mm}$ and age range of 22 to $66 \mathrm{~d}$ would suggest that $P$. scaber have the capacity to settle at a variety of sizes and ages. Moreover, the highest age recorded is probably conservative, as fish greater than $30 \mathrm{~mm}$ that had been fixed in formalin were not aged.

Although Parika scaber around drift and tethered algae often had a wide range of sizes and ages, the majority at any one time were of similar size and age. While a single sample would suggest that most fish settled at a similar size and age, this relation varied depending on the time it was examined. Our data indicated, therefore, that care should be taken in defining the typical duration of the presettlement phase based on a sample of fish from one time. Moreover, variation in the length of the presettlement phase of individuals has been found to vary between distant localities (5000 km; Victor 1986a) and may also be found to vary over smaller distances (e.g. 1 to $100 \mathrm{~km}$ ).

The capacity to settle at a variety of ages and sizes may be common in the Balistoidei (Aboussouan \& Leis 1984). Variability in the sizes of fish associated with drift, and captured around tethered algae, may reflect the occurrence of conditions which facilitate the onshore transport of fish. The slicks of internal waves, onshore winds and their associated windrows (Hamner \& Schneider 1986), have been suggested as important mechanisms for the onshore transport of planktonic fish (Shanks 1983, Kingsford \& Choat 1986). When onshore winds and slicks are common, fish may be transported onshore quickly, and settle on a reef. If offshore winds prevail, fish may spend a longer period as planktonic fish, and a greater age-size range may be expected at settlement.

Two patterns are suggested from the literature con- cerning the duration of the presettlement phase. In some species there is a broad range of ages at settlement (Randall 1961, Victor 1982) while others seem to exhibit little variation in age at settiement (e.g. Brothers et al. 1983). The latter case suggests one or a combination of the following: (1) To survive fish must arrive at a reef at a fixed time during their early development. (2) The close proximity of presettlement fish to a suitable juvenile habitat allows them to settle en masse when they reach a certain stage of development. (3) Most fish settle at a similar age, and those that settle at other times are rare and are unlikely to be sampled by biologists - especially if they have a low sample size. (4) Settlement marks in the otoliths of some species relate to morphological changes during ontogeny (e.g. Nishimura \& Yamada 1984) and do not relate to the act of settlement. (5) Fish that exhibit lunar periodicity in spawning and recruitment (Johannes 1978, Doherty 1983) may settle at similar ages and sizes at monthly or half-monthly intervals. Randall (1961), however, demonstrated for Acanthurus triostegas that the size range of fish settling at monthly intervals was considerably smaller than between monthly peaks. If the range of ages and sizes of a species is to be described at settlement, a large sample of fish should be captured on more than one occasion and preferably at more than one location. In many cases where little variation in the age of fish at settlement is inferred (e.g. Brothers et al. 1983) it may be due to low sample sizes and the collection of fish at one time or place. There have been no demonstrations that fish must arrive at a fixed time during their early development to survive and this is clearly not the case for Parika scaber. In fact, the capture of viable Thalassoma spp. larvae $1200 \mathrm{~km}$ from the nearest coral reef would suggest the opposite (Leis 1983). In general then, fish, like invertebrates (e.g. Scheltema 1968, Kempf 1981) may be capable of extending their presettlement period. This may be especially true for reef fish that commonly associate with drifting objects in the ocean e.g. Monacanthidae, Balistidae, Pomacentridae, Tripterygiidae, Blenniidae, Clinidae, and Syngnathidae (refs. in Kingsford \& Choat 1985).

It could be argued that the association of fish with drift and tethered algae indicates that the fish have settled and should not be considered presettlement individuals. However, the arrival of fish on the reef is described as the act of settlement (Williams 1983). Accordingly, what happens to fish prior to this must be considered the presettlement phase regardless of the behaviour of fish in the pelagic environment. Small fish and other zooplankters commonly respond to the presence of drift algae, diatomaceous mats, medusae and salps (Kingsford \& Choat 1985) and this should not be considered irregular behaviour. 


\section{Early life history of Parika scaber}

Parika scaber hatch from demersal eggs (Milicich 1986). Fish were not captured around drift algae below a size of $8 \mathrm{~mm}$. Over 1000 ichthyoplankton samples were collected by Kingsford (1986) with oblique and depth-stratified tows over the continental shelf from Leigh (Fig. 1). A total of only 50 P. scaber were captured over a $4 \mathrm{yr}$ period; the mean size of fish was $5.3 \mathrm{~mm}$, range 3.8 to $15 \mathrm{~mm}$. The maximum number caught with straight notochords in a single haul was 4 . This suggested 2 things: (1) concentrations of presettlement $P$. scaber $(<8 \mathrm{~mm})$ were low; $(2)$ because numbers were uniformly low in all tows, fish were well dispersed and unlikely to be found in large groups. Above a size of 8 to $9 \mathrm{~mm}$, however, large numbers of P. scaber were found around drift algae. Although fish were clumped around algae it was not an obligate relationship: fish were sometimes captured in open water and these were indistinguishable from those associated with drift algae (Kingsford \& Choat 1986).

The examination of Parika scaber from 3.5 to $27 \mathrm{~mm}$ indicated that fish develop from hatching into miniature replicas of adults at a size of 8 to $9 \mathrm{~mm}$. The notochord has undergone flexion, they have a full finray compliment and the pigmentation of fish on a reef by this stage. The smallest fish captured around tethered algae in January 1985 were 8 to $9 \mathrm{~mm}$ long; these fish were 22 to $23 \mathrm{~d}$ old. A change in the spacing of otolith increments occurred at this age. Transitions in otolith microstructure have been related to: hatching and changes from freshwater to saltwater environments (Volk et al. 1984), settlement (Victor 1982, Brothers et al. 1983, Brothers 1984), lunar cycles (Campana 1984) 'eco-behavioural transitions' (Brothers \& McFarland 1981), and the transition from a larval to a juvenile stage (Nishimura \& Yamada 1984). The plateau in increment spacing for $P$. scaber seems to indicate the development of fish to an adult form soon after flexion.

Ring spacing correlates with the growth of some fish (Taubert \& Coble 1977, Wilson \& Larkin 1982). Assuming that increment spacing was related to the growth of small Parika scaber, fish had a slow period of growth soon after hatching, followed by a rapid acceleration in growth to the stage at which flexion occurred. Clearly, $P$. scaber would have to be reared to see how growth relates to increment spacing and to their development prior to flexion. It seems likely, however, that this allometric growth coincides with the development of fins and the resulting increase in mobility. This increase in mobility may allow fish to increase their uptake of prey (Hunter 1981). Although increment spacings exhibited some variance once fish were of an age past flexion, mean values showed no upward or downward trends once the plateau was reached. This suggested, as do the linear (isometric) age-size relations, that the growth of presettlement fish is relatively constant once fish are well pigmented and have a full fin-ray complement. 'A curvilinear (or allometric) otolith length relationship is characteristic of many species during the larval phase while a linear relationship is usual for juveniles' (Campana \& Neilson 1985).

All of the relationships between age (days) and the spacing of increments showed an initial period of slow growth, followed by a rapid increase to a plateau. Fish captured on some dates, however, took much longer to reach the plateau than did other groups of fish. This suggested that the development rate, to well-pigmented fish, varied among sampling times. The conditions that fish experienced in the pelagic environment (e.g. prey densities and temperature) may have differed to cause these changes in development times.

It was demonstrated that the growth rates of Parika scaber varied among times. Moreover, we have speculated that the spacing of daily increments provides a history of growth for individual fish. Both the concentration of food and inputs from the physical environment may influence the growth of fish and be related to changes in increment spacings. Physical factors include photoperiod (Taubert \& Coble 1977, Tanaka et al. 1981) and temperature (Taubert \& Coble 1977, Neilson \& Geen 1982, 1985). We consider, as Jones (1986) does, that changes in natural photoperiod are small and unlikely to affect growth and consequently increment deposition. The Leigh Laboratory climate data would suggest that changes in seawater temperature would be small (range $2 \mathrm{C}^{\circ}$ ) within the time an individual spends as a presettlement fish. However, presettlement fish captured at different times during the reproductive period (i.e. spring vs summer) may have developed in seawater of quite different temperatures (e.g. 16 vs $22^{\circ} \mathrm{C}$ ). Temperature differences of 4 to $7 \mathrm{C}^{\circ}$ are large enough to cause differences in growth rate and increment spacing (e.g. Taubert \& Coble 1977). Hence temperature may have contributed to differences in growth and changes in increment spacing between fish caught in November and January (Fig. 7). A further alternative is that growth rates are determined from hatching. This may be due to the hatching of fish from eggs of different sizes (Mann \& Mills 1979). This explanation seems unlikely as egg sizes, and the sizes of newly hatched fish, generally decrease as the spawning season progresses (Daoulas \& Economou 1986). In this study lowest growth rates were found early in the spawning-recruitment period when large eggs would be expected. Without experimentally determining the effects of food densities, temperature, and egg size on subsequent growth and increment 
spacing, we can only speculate as to the causes of this variation within and amongst groups of fish.

In conclusion, this study has shown that there is natural variation in the growth rates between groups of fish captured at different times. The spacing of otolith increments also varied, both within and between fish. This showed that considerable insight may be gained on the growth history and development of individual fish from otoliths. Furthermore, the study suggested a number of areas that could be profitably investigated. How does variability in the size, age, and abundance of newly settled fish reflect the occurrence of conditions which facilitate the onshore transport of fish? What is the interaction between the abundances of prey and seawater temperature in influencing growth.

Do increment spacings in the otoliths of presettlement fish reflect changes in the growth history of individuals? Growth rates may influence the survivorship of presettlement fish if smallest individuals have higher mortality rates (Healey 1982); does this apply to reef fish? Is variability in the age and size at settlement unique for monacanthid and labrid fishes (Victor $1986 \mathrm{~b})$, or does this pattern also apply to other groups? Examining these questions will be helpful in determining the important processes influencing the survivorship of presettlement fish to recruitment on the reef.

Acknowledgements. This work was carried out at the University of Auckland Marine Laboratory. Financial assistance was provided by the laboratory, the University of Auckland Research committee, the Claude McCarthy Scholarship Foundation, and a New Zealand Fisheries Research Division Scholarship to M. J. Kingsford. In addition to his support and supervision of the project J. H. Choat gave many helpful comments on the manuscript. We thank J. Considine for his help with microscopy using fluorescent light. Special thanks to D. Allen, M. Atkinson, B. Hickey, P. Leake, M. Meekan, H. McNeill, K. Tricklebank, S. Thorold, and M. Uffindell for assistance in the field. Helpful criticisms of the manuscript were given by R. G. Creese, B. Gauldie, G. P. Jones, and R. Thresher.

\section{LITERATURE CITED}

Aboussouan, A., Leis, J. M. (1984). Balistoidei: development. In: Moser, H. G., Richards, W. J., Cohen, D. M., Fahay, M. P., Kendall, Jr. A. W., Richardson, S. L. (ed.) Ontogeny and systematics of fishes. Special Publ. No. 1, American Society of Ichthyologists and Herpetologists. Allen Press, Inc., Lawrence, p. 450-459

Ayling, A. M. (1981). The role of biological disturbance in temperate subtidal encrusting communities. Ecology 62: $830-847$

Ayling, T., Cox, G. J. (1982). Sea tishes of New Zealand Collins, Auckland

Brothers, E. B. (1984). Otolith studies. In: Moser, H. G., Richards, W. J., Cohen, D. M., Fahay, M. P., Kendall, Jr. A. W., Richardson, S. L. (ed.) Ontogeny and systematics of fishes. Special Publ. No. 1, American Society of Ichthy- ologists and Herpetologists. Allen Press, Inc., Lawrence, p. $50-57$

Brothers, E. B., McFarland, W. N. (1981). Correlations between otolith microstructure, growth, and life history transitions in newly recruited French Grunts (Haemulon flavolineatum, Desmarst, Haemulidae). Rapp. P.-v. Réun. Cons. int. Explor. Mer 178: 369-374

Brothers, E. B., Mathews, C. P., Lasker, R. (1976). Daily growth increments in otoliths from larval and adult fishes. Fish. Bull. U.S. 74:1-8

Brothers, E. B., Williams, D. McB., Sale, P. F. (1983). Length of larval life in twelve families of fish at 'One Tree Lagoon', Great Barrier Reef, Australia. Mar. Biol. 76: 319-324

Campana, S. E. (1984). Lunar cycles of otolith growth in the starry flounder Platichthys stellatus. Mar. Biol. 80: 239-246

Campana, S. E., Neilson, J. D. (1982). Daily growth increments in otoliths of starry flounder (Platichthys stellatus) and the influence of some environmental variables in their production. Can. J. Fish. Aquat. Sci. 39: 937-942

Campana, S. E., Neilson, D. (1985). Microstructure of fish otoliths. Can. J. Fish. Aquat. Sci. 42: 1014-1032

Daoulas, Ch., Economou, A. N. (1986). Seasonal variation of egg size in the sardine Sardina pilchardus Walb., of the Saronikos Gulf: causes and a probable explanation. J. Fish Biol. 28: $449-457$

Doherty, P. J. (1981). Coral reef fishes: recruitment - limited assemblages? Proc. 4th Int. Coral Reef Syrup. Manila 2: $465-470$

Doherty, P. J. (1983). Diel, lunar and seasonal rhythmus in the reproduction of two tropical damselfishes: Pomacentrus flavicauda and P. wardi. Mar. Biol. 75: 215-224

Hamner, W. N., Schneider, D. (1986). Regularly spaced rows of medusae in the Bering Sea: role of Langmuir circulation. Limnol. Oceanogr. 31: 171-177

Healey, M. C. (1982). Timing and relative intensity of size selective mortality of juvenile chum salmon (Oncorhynchus keta) during early sea life. Can. J. Fish. Aquat. Sci 39: 952-957

Hunter, J. R. (1981). Feeding ecology and predation of marine fish larvae. In: Lasker, R. (ed.) Marine fish larvae. University of Washington Press, Seattle, p. 34-59

Johannes, R. E. (1978). Reproductive strategies of coastal marine fishes in the tropics. Environ. Biol. Fish. 3: 65-84

Jones, C. (1986). Determining age of larval fish with the otolith increment technique. Fish. Bull. U.S. 84: 91-103

Jones, G. P. (1984). Population ecology of the temperate reef fish Pseudolabrus celidotus Bloch \& Schneider (Pisces: Labridae) 1. Factors influencing recruitment. J. exp. mar. Biol. Ecol. 75: 257-276

Jones, R. S. (1968). A suggested method for quantifying gut contents in herbivorous fishes. Micronesica 4: 369-371

Kempf, S. C. (1981). Long-lived larvae of the gastroped Aplysia juliana: do they disperse and metamorphose or just slowly fade away? Mar. Ecol. Prog. Ser. 6: 61-65

Kingsford, M. J. (1986). The distribution patterns of fish during the planktonic period of their life history. $\mathrm{Ph}$. D. thesis, Univ. of Auckland

Kingsford, M. J., Choat, J. H. (1985). The fauna associated with drift algae captured with a plankton-mesh purse seine net. Limnol. Oceanogr. 30: 618-630

Kingsford, M. J., Choat, J. H. (1986). The influence of surface slicks on the distribution and onshore movements of small fish. Mar. Biol. 91: 161-171

Leis, J. M. (1983). Coral reef fish larvae (Labridae) in the East Pacific Barrier. Copeia: 826-828

Leis, J. M. (1986). Vertical and horizontal distribution of fish 
larvae near coral reefs at Lizard Island, Great Barrier Reef. Mar. Biol. 90: 505-516

Leis, J. M., Goldman, B. (1984). A preliminary distributional study of fish larvae near a ribbon reef in the Great Barrier Reef. Coral Reefs 2: 197-203

Leis, J. M., Miller, J. M. (1976). Offshore distributional patterns of Hawaiian fish larvae. Mar. Biol. 36: 359-367

Leis, J. M., Rennis, D. S. (1983). The larvae of Indo-Pacific coral reef fishes. New South Wales University Press, Sydney

Lobel, P. S., Robinson, A. R. (1983). Reef fishes at sea: ocean currents and the advection of larvae. In: Reaka, M. L. (ed.) Ecology of deep and shallow reefs. NOAA Underwater Res. Prog. 1: 29-38

Mann, R. H. K., Mills, C. A. (1979). Demographic aspects of fish fecundity. In: Miller, P. J. (ed.) Fish phenology. Academic Press, London, p. 161-178

Milicich, M. J. (1986). Aspects of the early life history of Parika scaber (Pisces: Monacanthidae). M.Sc. thesis, Univ. of Auckland

Neilson, J. D., Geen, G. H. (1982). Otoliths of chinook salmon (Oncorhynchus tshawytscha): daily growth increments and the factors influencing their production. Can. J. Fish. Aquat. Sci. 39: 1340-1347

Neilson, J. D., Geen, G. H. (1985). Effects of feeding and diel temperature cycles on otolith increment formation in juvenile chinook salmon, Oncorhynchus tshawytscha. Fish. Bull. U.S. 83: 91-101

Nishimura, A., Yamada, J. (1984). Age and growth of larval and juvenile walleye pollock, Theragra chalcogramma (Pallas), as determined by otolith daily growth increments. J. exp. mar. Biol. Ecol. 82: 191-205

Radtke, R. L., Waiwood, K. G. (1980). Otolith formation and body shrinkage due to fixation in larval cod (Gadus morhua). Tech. Rep. Can. Fish. Aquat. Sci. No. 929: 1-9

Ralston, S., Miyamoto, T. (1983). Analysing the width of daily otolith increments to age the Hawaian snapper, Fristipomoides filamentosus. Fish. Bull. U.S. 81: 523-535

Randall, J. E. (1961). A contribution to the biology of the convict surgeonfish of the Hawaiian islands, Acanthurus triostegus sandvicensis. Pacif. Sci. 15: 215-272

Russell, B. C. (1977). Population and standing crop estimates for rocky reef fishes of north-eastern New Zealand. N.Z. Il mar. Freshwat. Res. 11: 23-36

Sale, P. F. (1980). The ecology of fishes on coral reefs. Oceanogr. mar. Biol. A. Rev. 18: 367-421

Scheltema, R. S. (1968). Dispersal of larvae by equatorial ocean currents and its importance on zoogeography of shoal-water species. Nature, Lond. 217; 1159-1162

Schmitt, P. D. (1984). Marking growth increments in otoliths of larval and juvenile fish by immersion in tetracycline to examine the rate of increment formation. Fish. Bull. U.S. 82: $237-242$
Shanks, A. L. (1983). Surface slicks associated with tidally forced internal waves may transport pelagic larvae of benthic invertebrates and fishes shoreward. Mar. Ecol. Prog. Ser. 13: 311-315

Sissenwine, M. P. (1984). Why do fish communities vary? In: May, R. M. (ed.) Exploitation of marine communities. Springer-Verlag, Berlin, p. 50-94

Struhsaker, P., Uchiyama, J. H. (1976). Age and growth of the nehu, Stolephorus purpureus (Pisces: Engraulidae), from the Hawaiian islands as indicated by daily growth increments of sagittae. Fish. Bull. U.S. 74: 9-17

Tanaka, K., Mugiya, Y., Yamada, J. (1981). Effects of photoperiod and feeding on daily growth patterns in otoliths of juvenile Tilapia nilotica. Fish. Bull. U.S. 79: 459-466

Taubert, B. D., Coble, D. W. (1977). Daily rings in otoliths of three species of Lepomis and Tilapia mossambica. J. Fish. Res. Bd Can. 34: 332-340

Tsuji, S., Aoyama, T. (1982). Daily growth increments observed in otoliths of the larvae of Japanese sea bream Pagurus major (Temminck et Schlegel). Bull. Jap. Soc. scient. Fish. 48: 1559-1562

Tucker, Jr., J. W., Chester, A. J. (1984). Effects of salinity, formalin concentration and buffer on quality of preservation of southern flounder (Paralichthys lethostigma) larvae. Copeia: 981-988

Victor, B. C. (1982). Daily growth increments and recruitment in two coral-reef wrasses, Thalassoma bifasciatum and Thalassoma bivittatus. Mar. Biol. 71: 203-208

Victor, B. C. (1983). Recruitment and population dynamics of a coral reef fish. Science 219: 419-420

Victor, B. C. (1986a). Duration of the planktonic stage of one hundred species of Pacific and Atlantic wrasses (family Labridae). Mar. Biol. 90: 317-326

Victor, B. C. (1986b). Delayed metamorphosis with reduced larval growth in a coral reef fish (Thalassoma bifasciatum). Can. J. Fish. Aquat. Sci. 43: 1208-1213

Voik, E. C., Wissmar, R. C., Siemenstad, C. A., Eggers, D. M. (1984). Relationship between otolith microstructure and the growth of juvenile chum salmon (Oncorhynchus keta) under different prey rations. Can. J. Aquat. Sci. 41: $126-133$

Williams, D. McB. (1983). Daily, monthly and yearly variability in recruitment of a guild of coral reef fishes. Mar. Ecol. Prog. Ser. 10: 231-237

Wilson, K. H., Larkin, P. A. (1980). Daily rings in the otoliths of juvenile sockeye salmon (Oncorhynchus nerka). Can. J. Fish. Aquat. Sci. 37: 1495-1498

Wilson, K. H., Larkin, P. A. (1982). Relationship between thickness of daily growth increments in sagittae and change in body weight of sockeye salmon (Oncorhynchus nerka) fry. Can. J. Fish. Aquat. Sci. 39: 1335-1339 